\title{
Coordination-Driven Assembly of Molecular Clefts
}

\author{
Kuk Min Han and Kyu-Sung Jeong* \\ Department of Chemistry, Yonsei University, Seoul 120-749, Korea \\ Received April 3, 2003
}

Key Words : Self-assembly, Molecular cleft, Coordination, Hydrogen bond

Concerted multi-point interactions are a prerequisite for selective and strong bindings between receptor and substrate. To do so, wo or more binding groups must be covalently connected to an appropriate spacer that provides the right distance and orientation complementary to a target substrate. This covalent method is highly reliable but requires multi-step, lime-consuming synthesis. $\Lambda \mathrm{n}$ alternative method is to use the sell-assembly that collects molecular lragments in a preprogrammed way to yicld the desired receptor. Due to its proper strength and directionality, the metal-ligand interaction has been demonstrated to be most useful for this purpose and successfully implemented for the self-assembly of numerous macrocycles and cages.' I lowcver, only a few of noncovalent. self-assembled molecular clelts have been reported to date, ${ }^{2}$ despite a wide spread use of covalent counterparts as artilicial receptors.

We reported a few years ago the self-assembly of discrete, neutral macrocycles by the combination of osmium tetraoxide, alkene, and bispyridyl ligand." Using this selfassembling motif, we have here prepared new molecular clelts $2 \mathbf{a}, \mathbf{2 b}$ and $\mathbf{2} \boldsymbol{c}$ that are capable of binding a terephthalamide by multiple hydrogen bonds. The hydrogen bonding sites of $\mathbf{2 a}, \mathbf{2 b}$ and $\mathbf{2 c}$ are based on the pyridine-2,6dicarboxamide scaffold where two amide hydrogens are

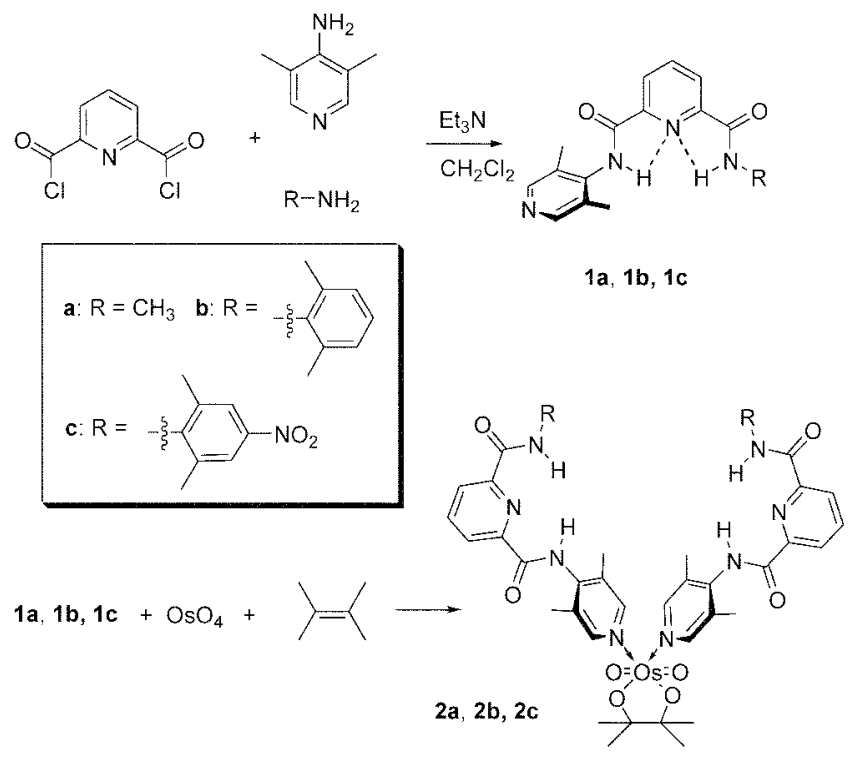

Scheme 1 inwardly oriented by a virluc of weak, internal N (pyridyl) $\cdots \mathrm{H}$ $\mathrm{N}$ (amide) hydrogen bonds. Owing to the conlormational rigidity, the pyridine-2,6-dicarboxamide skeleton has been used as an important building block for the construction of many supramolecular structures. ${ }^{*}$

Ligands 1a, $\mathbf{l b}$ and $\mathbf{l c}$ were prepared in one pot by sequential coupling reactions of pyridine-2,6-dicarbonyl dichloride with 4-amino-3,5-lutidine ${ }^{5}$ and the corresponding amine (aminomethane, 2,5-dimethylaniline or 2,5-dimethyl4-nitroaniline ${ }^{6}$ ) in 18-22\% isolated yiclds. When each of the ligands was mixed with osmium telraoxide and 2,3-dimethyl-2-butene in an equal molar ratio. the clelis $\mathbf{2 a}, \mathbf{2 b}$ and $\mathbf{2 e}$ were self-assembled within a few minutes. The reactions proceeded quantitatively but the isolated yiclds were 70 $79 \%$. Elemental analyses and spectroscopic data were all consistent with the struetures of the clefts $2 \mathbf{a}, \mathbf{2 b}$ and $2 \mathbf{c}$. $^{7}$

The binding ability of the clelts $\mathbf{2 a}, \mathbf{2 b}$ and $\mathbf{2 c}$ was revealed by 'I ] NMR titration experiments, using $N, N, N$, N'tetramethylterephthalamide (3) as the guest. The experiments were performed at $24 \perp 1{ }^{\circ} \mathrm{C}$ by the addition of the guest solution (10 $\mathrm{mM}$ in $\left.\mathrm{CDCl}_{3}\right)$ to a $\mathrm{CDCl}_{3}$ solution containing each cleft ( $2 \mathrm{mM}$ in C.DCl: $)$. Under these conditions, timeaveraged resonances for the free and the complexed species were always observed. Two NIl signals of the cleft were largely downfield shifted upon addition of 3 , indicative of hydrogen bonding formation. For example, 1wo NI I signals of the cleli $\mathbf{2 b}$ were gradually downlicld shifted from 8.94 and $9.32 \mathrm{ppm} 109.70$ and $10.60 \mathrm{ppm}$, respectively. Nonlinear least squares fitting methods ${ }^{8}$ of these titration curves gave the association constant of $360 \perp 20 \mathrm{M}^{-1}$ between $\mathbf{2 b}$ and $\mathbf{3}$. The titration curves generated from both N] changes gave essentially an identical association constant within experimental etror $(<10 \%)$, indicating that both NIs are participated in the same binding event. Job plot confirmed a $1: 1$
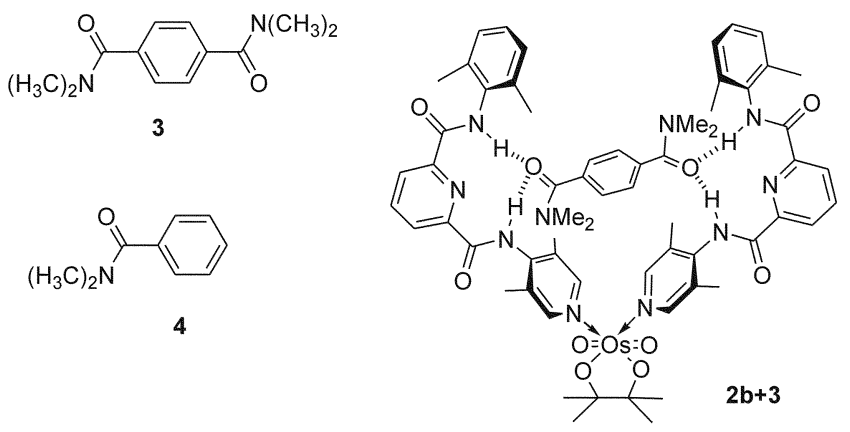

Scheme 2 
(2b/3) stoichiometry of the complex, showing the maximum complex formation at the mol fraction of 0.5 .

When the cleft 2 b was titrated with a monoamide, $N, N$ dimethylbenzamide (4) under the same conditions. the $\mathrm{NH}$ chemical shift changes were too small $(\Delta \delta<0.1 \mathrm{ppm})$ to determine accurately the association constant $\left(K_{\mathrm{a}}<5 \mathrm{M}^{-1}\right)$. This observation strongly supports that two pyridinedicarboxamide binding sites of $\mathbf{2} \mathbf{b}$ are simultaneously involved in the binding to form multiple hydrogen bonds with the dianide guest 3 . like in a proposed structure of the contplex $(\mathbf{2 b}+\mathbf{3}$. Scheme 2). Finally. association constants of other clefts, $2 \mathrm{a}$ and $\mathbf{2 c}$. with 3 were determined to be $80 \pm 10 \mathrm{M}^{-1}$ and $480 \pm 20 \mathrm{M}^{-1}$, respectively, under the same conditions. These results suggest that the arylamide $\mathrm{NH}$ (in $\mathbf{2 b}$ and $\mathbf{2 c}$ ) is better hydrogen-bonding donor than the alkylamide $\mathrm{NH}$ (in 2a) and the nitro substituent at the para position (in 2c) slightly increases the hydrogen donor ability.

In conclusion. three molecular clefts have been selfassembled by simply mixing osmium tetraoxide. 2.3dimethyl-2-butene, and pyridyl ligands. The clefts have two hydrogen-bonding sites in a convergent way and bind a dianide guest by multiple hydrogen bond formation. The cleft can be conveniently modified at will by the variation of the ligand. and consequently this approach may provide an opportunity to construct more elaborate molecular cleft-type receptors.

Acknow ledgement. This work was supported by the grant from Yonsei University.

\section{References}

1. For reviews see: (a) Fujita. M. Chent. Soc. Rev 1998. 27. 417. (b) Caulder D. L.: Raymond. K. N. Acc. Chem. Res. 1999, 32,975. (c) Leiminger. S.: Olenyuk. B.: Stang. P. I. Chent. Rev $2000,100$. 853. (d) Swiegers, G. F.: Malefetse. T. I. Chem. Rev $2000,100$. 3483. (e) Sun. S.-S.: Lees. A. J. Coond Chem. Rew. 2002. 230. 171

2. (a) Goodman. M. S.: Weiss. J.: Hamilton. A. D. Tetrahedron Lett. 1994. 35, 8943. (b) Goodnan. M. S.: Hamilton. A. D.: Weiss, J. $J$.
Am. Chem. Soc. 1995. 117. 8447. (c) Linton. B.: Hamilton. A. D. Chent. Rev: 1997.97. 1669

3. (a) Jeong, K.-S.: Cho, Y. L.: Song. J. U.: Chang. H.-Y; Choi. M.G. J. Ant Chem. Soc. 1998, 120. 10982 (b) Jeong. K.-S.: Cho. Y. L. Chang, S.-Y.: Park, T.-Y, Song, J. U. J. Org. Chem. 1999, 64. 9459. (c) Jeong. K.-S.: Lee. J. W.: Park. T.-Y.: Chang. S.-Y. Chem. Commun 1999. 2069. (d) Cho. Y. L.: Uh. H.: Chang. S.-Y: Chang. H.-Y.: Choi. M.-G.: Shin. I.: Ieong. K.-S. J. Ant Chent Soc. $2001,123,1258$.

4. (a) Hunter, C. A.; Purvis, D. H. Angew: Chem. In. Ed. Engl. 1992. 31, 792 (b) Hamuro, Y.: Geib, S. J: Hamilton, A. D. J. Am. Chem. Soc. 1997. 119. 10587. (c) Crisp. G. T.: Tiang. Y.L. Tetrahedron 1999. 55. 549. (d) Moriuchi. T.: Nishiyama. M. Yoshida. K.: Ishikawa. T.: Hirao. T. Org. Lett. 2001. 3. 1459. (e) Preston. A. J.; Fraenkel, G.; Chow: A.: Gallucei. J. C.: Parquette. J. R J. Org. Chem. 2003. 68. 22.

5. (a) Malinowski. M.: Kaczmarek, L. I. Prakt. Chem. 1988. 330. 154. (b) Essery. T. M.: Schofield. K. J. Chem. Soc. 1960. 4953.

6. Wepster. B. M. J Roval Wethertands Chem. Soc. 1954. 73. 809.

7. Physical and spectroscopic properties. 2a: dark brown solids. mp $3100^{\circ} \mathrm{C}$ (decomp). $\mathbb{R}(\mathrm{KBr}) 3448,1670.831 \mathrm{~cm}^{-1}$. 'H NMR $\left(\mathrm{CDCl}_{3} .250 \mathrm{MHz}\right) \delta 9.42(\mathrm{~s}, 2 \mathrm{H}, \mathrm{NH}), 8.62(\mathrm{~s}, 4 \mathrm{H}) .8 .44(\mathrm{~d}, J=$ $7.7 \mathrm{~Hz} .4 \mathrm{H}) .8 .12(\mathrm{t} . J=7.7 \mathrm{~Hz}, 2 \mathrm{H}), 7.74(\mathrm{br} \mathrm{s} .2 \mathrm{H} . \mathrm{NH}) .3 .08(\mathrm{~d}$, $J=4.8 \mathrm{~Hz} .6 \mathrm{H}$ ). 2.28 (s. $12 \mathrm{H}$ ). 1.48 (s. $12 \mathrm{H}$ ). ${ }^{13} \mathrm{C} \mathrm{NMR}(\mathrm{CDCl})_{3}$. $63 \mathrm{MHz}) \delta$ I64.7. 162.2. 149.6. 148.8. 140.1. 132.4. 90.7. 54.1. 27.1. 25.3. 16.9. Anal. Caled for $\mathrm{C}_{36} \mathrm{H}_{44} \mathrm{~N}_{8} \mathrm{O}_{8} \mathrm{Os}: \mathrm{C}$. 47.67: $\mathrm{H}$. 4.88, N, 12.35. Found: C. 47.70: H. 4.87: N, 12.30. 2b: dark brown solids, mp $100^{\circ} \mathrm{C}$ (decomp). IR ( $\mathrm{KBr}$ ) 3448, 1686,830 $\mathrm{cm}^{-1} .{ }^{1} \mathrm{H} \mathrm{NMR}\left(\mathrm{CDCl}_{3}, 250 \mathrm{MHz}\right) \delta 9.32$ (s. 2H. NH). 8.94 (s, $2 \mathrm{H}$. NH). 8.65 (s. $4 \mathrm{H}) .8 .54(\mathrm{~d} . J=7.8 \mathrm{~Hz} .4 \mathrm{H}) .8 .20(\mathrm{t} . J=7.8 \mathrm{~Hz}$. $2 \mathrm{H}) .7 .18-7.11$ (m. $6 \mathrm{H}) .2 .31$ (s. $24 \mathrm{H}$ ). 1.47 (s. $12 \mathrm{H}$ ). ${ }^{13} \mathrm{C} \mathrm{NMR}$ $\left(\mathrm{CDCl}_{3} .63 \mathrm{MHz}\right) \delta 161.3 .160 .8 .148 .8 .148 .5 .148 .1 .146 .6$. $146.4,137.4 .134 .0,126.9 .123 .7,123.6 .1200 .90 .5 .250 .19 .4$. 16.5. Anal. Calcd for $\mathrm{C}_{50} \mathrm{H}_{56} \mathrm{~N}_{3} \mathrm{O}_{3} \mathrm{Os:}$ C. $55.24: \mathrm{H} .5 .19 ;$ N. 10.31 . Found: C. 55.24, H. 5.20: N, 12.29. 2c: dark brown solids. $m p$ $100{ }^{\circ} \mathrm{C}$ (decomp). IR (KBr) 3445. $1699.826 \mathrm{~cm}^{-1}$. ' $\mathrm{H}$ NMR $\left(\mathrm{CDCl}_{3} .250 \mathrm{MHz}\right) \delta 9.30$ (s. $2 \mathrm{H} . \mathrm{NH}$ ). 9.09 (s. $2 \mathrm{H}$. NH). 8.64 (s. $4 \mathrm{H}) .8 .56(\mathrm{~d} . J=7.8 \mathrm{~Hz} .4 \mathrm{H}) .8 .20(\mathrm{t} . J=7.8 \mathrm{~Hz} .2 \mathrm{H}) .8 .01$ (s. $4 \mathrm{H}) .2 .42(\mathrm{~s}, 12 \mathrm{H}) .2 .31(\mathrm{~s}, 12 \mathrm{H}), 1.46(\mathrm{~s} .12 \mathrm{H}) .{ }^{13} \mathrm{C} \mathrm{NMR}(\mathrm{CDCl}$. $63 \mathrm{MHz}) \delta 161.5 .161 .3,149.4,148.6 .148 .5 .148 .0,140.0135 .3$ $133.2,130.9,128.6,127.9 .126 .7 .90 .2 .24 .8 .18 .8 .16 .4$.

8. Macomber. R. S. J. Chem. Educ. 1992. 69. 375.

9. (a) Connors. K. A. Binding Constants: Tohn Wiley \& Sons: New York. 1987. (b) Schneider. H.-T: Yatsimirshy. A. K. Principles and Methods in Supranolecular Chemismy, John Wiley \& Sons: New York. 2000. 